\title{
ANALYSIS OF THE CORROSION OF CARBON STEELS IN SIMULATED SALT REPOSITORY BRINES AND ACID CHLORIDE SOLUTIONS AT HIGH TEMPERATURES*
}

\author{
D. R. Diercks and T. F. Kassner \\ Materials and Components Technology Division \\ Argonne National Laboratory \\ Argonne, IL 60439

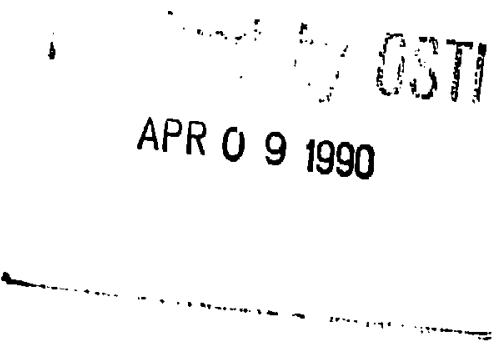

April 1988

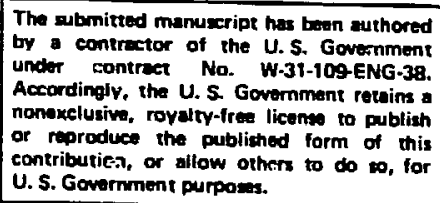

\section{DISCLAIMER}

This report was prepared as an account of work sponsored by an agency of the United States the United States Government nor any agency thereof, nor any of their Government. Neither the United States or implied, or assumes any legal liability or responsiemployees, makes any warranty, express or implied, or as information, apparatus, product, or bility for the accuracy, completeness, or usefulness of any ininge privately owned rights. Referprocess disslosed, or represents that its use would nocess, or service by trade name, trademark, ence herein to any specific commercial product, proces, or imply its endorsement, recommanufacturer, or otherwise does not necessarily constitute or imply inency thereof. The views mendation, or favoring by the United States Governmessarily state or reflect those of the and opinions of authors expressed herein do not

United States Government or any agency thereof.

* Work sponsored by the U. S. Department of Energy. Salt Repository Project, under contract W-31-109-Eng-38.

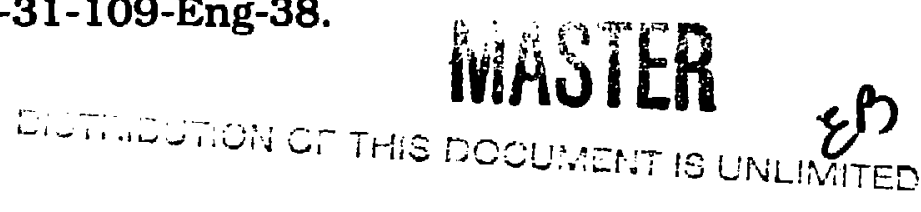




\begin{abstract}
An analysis of literature data on the corrosion of carbon steels in anoxic brines and acid chloride solutions was performed, and the results were used to assess the expected life of high-level nuclear waste package containers in a salt repository environment. The corrosion rate of carbon steels in moderately acidic aqueous chloride environments obeys an Arrhenius dependence on temperature and $\mathrm{a}\left(\mathrm{p}_{\mathrm{H}_{2}}\right)^{-1 / 2}$ dependence on hydrogen partial pressure. The cathodic reduction of water to produce hydrogen is the rate-controlling step in the corrosion process. An expression for the corrosion rate incorporating these two dependencies was used to estimate the corrosion life of several proposed waste package configurations. All but the lowest temperature package would undergo excessive corrosion during the anticipated 1000-year emplacement time. and the calculated pressure of corrosion product hydrogen would exceed the lithostatic pressure of the repository before the end of the emplacement period. Thermally driven brine migration to the container could limit the corrosion rate; however, measured rates of nonthermal brine migration to test boreholes would be sufficient to support excessive corrosion of the container, if they were to persist over long time periods. Thus, the corrosion resistance of a carbon steel container is probably not sufficient to attain virtually complete containment of the waste over a 1000-year emplacement period in a salt repository.
\end{abstract}


Bedded salt formations have been proposed as possible geological sites for the long-term disposal of high-level nuclear waste. Proposed U. S. Nuclear Regulatory Commission regulations require that the nuclear waste package provide essentlally complete waste isolation for a minimum of up to 300 to 1000 years after emplacement (1). The longterm corrosion resistance of the waste package outer container in the salt repository environment is a major factor in meeting these requirements, since the container is the primary structural and corrosion barrier. Brine entrapped in the salt can migrate to the container by several transport processes: consequently, corrosion of the container can occur at temperatures from about 323 to $473 \mathrm{~K}$, depending upon the waste package configuration.

Carbon steel, namely, cast A216 Grade WCA, was selected as a leading candidate for the waste package outer container in the salt repository. This alloy was chosen on the basis of its availability, cost. mechanical strength, and fabrication characteristics. In addition, preliminary analyses indicated that the steel would corrode at an acceptably low uniform rate in the salt repository environment and that its resistance to localized corrosion, including pitting and stress corrosion cracking, was satisfactory (2).

The present work examines in more detail the suitability of carbon steel for use as a waste package container material in a salt repository. The analysis makes use of corrosion data for carbon steels in simulated salt repository environments, including more aggressive high- $\mathrm{Mg}^{2+}$ brines, most of which were obtained after the initial alloy selection. Included are data in more aggressive high- $\mathrm{Mg}^{2+}$ brines. Extensive literature data on the corrosion of carbon steels in geothermal brines and 
other anoxic acid chloride solutions were also utilized in this analysis. Thus, the results are relevant to a variety of applications involving the exposure of carbon steels to anoxic acid chloride solutions at elevated temperatures.

\section{Chemistry of Salt Repository Brines}

The brines likely to contact a nuclear waste package in a salt repository may be classified as either intrusion or inclusion brines. The intrusion brines are created through the dissolution of some of the host rock salt by external water introduced into the repository. In the case of the bedded salt deposits of the Deaf Smith County, Texas waste repository site, the intrusion brines consist primarily of $\mathrm{NaCl}$, with small amounts of $\mathrm{Mg}$ and $\mathrm{Ca}$. Table I gives a typical brine composition (PBB1) obtained by the dissolution of salt cores from the Permian Basin salt horizon in Texas.

The inclusion brines are naturally present in small quantities as fluid pockets in the bedded salt. Since these inclusions tend to migrate toward the container/salt interface under the influence of a thermal gradient, they must be considered in an evaluation of the corrosion performance of the waste package material. PBB3 in Table I represents a typical composition of a fluid inclusion from analyses of samples of a Permian Basin salt horizon core. The significantly higher $\mathrm{Mg}$ and $\mathrm{Ca}$ contents are characteristic of an inclusion brine, and this feature has also been observed in samples from the Paradox Basin bedded salt deposit in Utah (4). 
Corrosion data obtained on A216 Grade WCA carbon steel in simulated repository brines indicate substantially higher corrosion rates in high- $\mathrm{Mg}^{2+}$ inclusion brines than in low- $\mathrm{Mg}^{2+}$ intrusion brines, particularly at temperatures above room temperature $(3,5-9)$. It was suspected that these differences are due to the hydrolysis of $\mathbf{M g}^{2+}$, which thereby causes the brines to become acidic. This, in turn, influences the protective nature and stability of the magnetite corrosion product layer $(10,11)$.

Calculations of brine $\mathrm{pH}$, based upon the following idealized hydrolysis reactions, were performed:

$$
\begin{aligned}
& \mathrm{Mg}^{2+}+\mathrm{H}_{2} \mathrm{O}=\mathrm{MgOH}^{+}+\mathrm{H}^{+} \\
& \mathrm{MgOH}^{+}+\mathrm{H}_{2} \mathrm{O}=\mathrm{Mg}(\mathrm{OH})_{2}+\mathrm{H}^{+}
\end{aligned}
$$

Thermodynamic constants for the dissociation of water and for the above two hydrolysis reactions were taken from the literature (12), and the resulting calculated $\mathrm{pH}$ values versus temperature for PBB1, PBB3, and seawater (1270 ppm $\left.\mathrm{Mg}^{+}\right)$are shown in Fig. 1. The decrease in $\mathrm{pH}$ with increasing temperature and $\mathrm{Mg}^{2+}$ concentration is clearly indicated. These calculations ignore the effect of other constituents in the brine on $\mathrm{pH}$, and the values indicated in Fig. 1 are only an approximation to the actual $\mathrm{pH}$ values for these multicomponent brines. Nonetheless, the potentially significant effect of $\mathrm{Mg}^{2+}$ hydrolysis on brine $\mathrm{pH}$ is clearly indicated. 


\section{Corrosion Data for Carbon Steel}

The above calculations confirm the tendency of $\mathrm{Mg}^{2+}$ cations in $\mathrm{Mg}$ containing brines to hydrolyze and decrease brine $\mathrm{pH}$. The present review, therefore, concentrates on the corrosion of iron and plain-carbon steels in anoxic, moderately acidic $\left(\mathrm{pH}_{25}^{\circ} \mathrm{C}=4-6\right)$ brines containing hydrolyzable species such as $\mathrm{Mg}^{2+}, \mathrm{Ni}^{2+}, \mathrm{Fe}^{2+}$, and $\mathrm{Ca}^{2+}$ or chloride solutions acidified by $\mathrm{HCl}$. A total of 261 data points, presented in detail elsewhere (13), have been obtained from the literature.

More that half (151 data points) of the literature data was obtained from corrosion studies conducted in simulated salt repository brines (3, 5-9, 14-16). The remaining data are from studies in geothermal brines (17-25). acidified simulated nuclear reactor coolants $(11,26,27)$, acidified seawater (28), boiling salt solutions (29), acidified $\mathrm{NaCl}$ solutions (30), and refrigerant brines (31). Results from short-term tests (most of the data are for test times $>600 \mathrm{~h}$ ), neutral or basic solutions, aerated solutions, and strongly agitated or rapidly flowing solutions were specifically excluded from the data base.

The anoxic acid chloride corrosion rate data are summarized in Table II and plotted in Fig. 2. The data obey an Arrhenius relation over the temperature range from 293 to $673 \mathrm{~K}$. The corrosion rate $P$ in $\mathrm{mm} / \mathrm{yr}$, as indicated by the best-fit line to Fig. 2, is given by the expression

$$
P=3866 \cdot \exp (-31,960 / R T) \text {, }
$$


where the gas constant $R$ is $8.314 \mathrm{~J} /$ mole. $K$ and $T$ is the temperature in K. An "upper-bound" corrosion rate indicated by the dashed line in the figure encompasses essentially all of the data at temperatures below $523 \mathrm{~K}$ and lies above the best-fit line by a factor of five.

\section{Possible Partial Corrosion Processes}

The corrosion of iron in anoxic, moderately acidic chloride solutions containing $\mathrm{Mg}^{2+}$ results in the formation of either magnetite $\left(\mathrm{Fe}_{3} \mathrm{O}_{4}\right)$ or amakinite $(5,8)\left[\mathrm{Mg}, \mathrm{Fe}(\mathrm{OH})_{2}\right]$ according to the overall reactions

$$
3 \mathrm{Fe}+4 \mathrm{H}_{2} \mathrm{O}=\mathrm{Fe}_{3} \mathrm{O}_{4}+4 \mathrm{H}_{2}
$$

or

$$
\mathrm{Fe}+2 \mathrm{H}_{2} \mathrm{O}+\left(\mathrm{Mg}^{2+}\right)=\mathrm{Mg}, \mathrm{Fe}(\mathrm{OH})_{2}+\mathrm{H}_{2}
$$

The corresponding anodic partial process is given by the reaction

$$
\mathrm{Fe}=\mathrm{Fe}^{2+}+2 \mathrm{e}^{-}
$$

Electrochemical corrosion processes generally obey Faraday's Law, where the corrosion penetration or dissolution rate is given by

$$
\dot{\mathbf{a}}=\frac{\mathrm{M}_{\mathrm{Fe}} \cdot \mathbf{i}_{\mathrm{a}}}{\mathrm{z} \rho \mathrm{F}}
$$

where $\mathrm{MFe}_{\mathrm{Fe}}$ is the molecular weight of iron, $i_{\mathrm{a}}$ is the anodic current density $\left(\mu \mathrm{A} / \mathrm{cm}^{2}\right), z$ is the charge of the metal ion, $\rho$ is the density of the 
metal, and $\mathrm{F}$ is Faraday's constant. For iron, the anodic dissolution rate a $(\mathrm{mm} / \mathrm{yr})=1.13 \times 10^{-2}\left(\mathrm{I}_{\mathrm{a}}\right)$. When dissolution in Eq [6] is accompanied by hydrolysis and mass transport of corrosion product species away from the surface, the steady-state flux of metal ions or of the hydrolyzed species can be represented by Fick's Law, i.e.,

$$
J=-D \frac{\partial c}{\partial x}
$$

where $D$ is the diffusion coefficient of the particular species, and $\frac{\partial c}{\partial x}$ is the concentration gradient in the liquid at the metal-electrolyte interface. If the concentration of the corrosion product in the bulk solution is small in comparison with the surface concentration, e.g., the solubility concentration of $\left[\mathrm{Fe}^{2+}\right]$ or $\left[\mathrm{Fe}\left(\mathrm{OH}^{+}\right)\right]$, the flux is approximated by

$$
J=-D \frac{\left[\mathrm{Fe}^{2+}\right]}{\Delta \mathbf{x}}
$$

In terms of the equilibrium relation for Eq. [6], the penetration rate can also be represented by

$$
\dot{\mathrm{a}}=\mathrm{K}_{1} \cdot\left[\mathrm{Fe}^{2+}\right]=\frac{\mathrm{K}_{2}}{\left[\mathrm{e}^{-}\right]^{2}}
$$

where $\left[e^{-}\right]$is the concentration of aqueous electrons from the anodic dissolution reaction. Equation [10] implies that the corrosion rate could be influenced by the solubility of the corrosion product as well as by mass transport of ferrous ions away from the surface; i.e., anodic dissolution increases as the concentration of dissolved iron increases or as the 
concentration of electrons at the metal-electrolyte interface decreases. To sustain the dissolution reaction, a cathodic reduction partial process must also occur in which the aqueous electrons produced in Eq. [6] are consumed in either the reduction of water or hydrogen lons.

Posey et al. (32) investigated the corrosion of Type A212B carbon steel in deaerated $4 \mathrm{M} \mathrm{NaCl}$ solutions as a function of $\mathrm{pH}$, temperature ( 298 to $473 \mathrm{~K}$ ), and velocity, by means of electrochemical measurements. For solutions with room-temperature $\mathrm{pH}$ values of 5 to 7 , their results closely agree with our best-fit curve. Eq. [3], to 261 data points for the corrosion of various carbon steels in anoxic acid chloride solutions. In particular, their experimental activation energy of $33.9 \mathrm{~kJ} / \mathrm{mol}$ compares favorably with our value of $31.9 \mathrm{~kJ} / \mathrm{mol}$ (Fig. 2). Posey et al. determined that the corrosion process in this temperature and $\mathrm{pH}$ regime was controlled by the cathodic reduction of water, i.e.

$$
\mathrm{H}_{2} \mathrm{O}+\mathrm{e}^{-}=\mathrm{H}^{\circ}+\mathrm{OH}^{-} \text {. }
$$

with the hydrogen adatoms subsequently combining to form hydrogen gas. In basic solutions, Posey et al. found that the corrosion rates were lower, apparently because of the formation of a protective magnetite surface film. In strongly acidic solutions, higher corrosion rates than are indicated in Fig. 3 were observed, and the rate-controlling process was attributed to the cathodic reduction of the abundant hydrogen ions with an activation energy $\sim 17.6 \mathrm{~kJ} / \mathrm{mol}$.

On the basis of the excellent agreement between the two best-fit curves of Fig. 3, the rate-controlling partial process for the corrosion of iron in anoxic, moderately acid salt repository brines and similar 
solutions (data shown in Fig. 2). is apparently also the reduction of water, i.e., Eq. [11], The limiting cathodic current density $i_{c}$ for this ratelimiting step couples with the anodic dissolution current density $i_{a}$.

$$
\left|\mathbf{i}_{\mathbf{c}}\right|=\left|\mathbf{i}_{\mathrm{a}}\right|
$$

Similarly to Eq. [10], the corrosion or penetration rate under conditions of cathodic reduction control for Eq. [11] can be written as

$$
\dot{\mathrm{a}}=\frac{\mathrm{K}_{3}}{\left[\mathrm{e}^{-}\right]}=\frac{\mathrm{K}_{3}}{\left[\mathrm{H}^{\mathrm{O}}\right] \cdot\left[\mathrm{OH}^{-}\right]}=\frac{\mathrm{K}_{3} \cdot\left[\mathrm{H}^{+}\right]}{\mathrm{K}_{\mathrm{w}^{\prime}} \cdot\left[\mathrm{H}^{\mathrm{O}}\right]}
$$

where $K_{w}$ is the equilibrium constant for the dissociation of water. If one compares the dependence of the corrosion rate on the electron concentration at the electrolyte-metal interface under anodic dissolution control, Eq. [10], and under cathodic reduction contsol, Eq. [13], the rate varies as $1 /\left[\mathrm{e}^{-}\right]^{2}$ in the former case and as $1 /\left[\mathrm{e}^{-}\right]$in the latter case; however, the amount of hydrogen produced in the overall reactions, Eq. [4] and [5], will be the same irrespective of the rate-controlling partial process. Although two electron transfer events, depicted by Eq. [11], must occur for each iron atom that dissolves, Eq. [6], the ratecontrolling cathodic reduction partial process occurs in a manner that is independent of overall stoichiometry. In other words, electrons are being consumed at the interface as a rate dictated by the kinetics of the reduction process in Eq. [11]; secondarily, in the case of iron dissolution (an inherently more rapid process), one atom dissolves as two electrons undergo reaction with two water molecules. 
The dependence of the corrosion rates on the partial pressure or fugacsty of hydrogen gas under cathodic reduction control can be obtained by combining Eq. [13] with the equilibrium relation for the combination of hydrogen adatoms to form diatomic hydrogen gas, i.e., $\mathrm{K}_{\mathrm{eq}}$ $=\left[\mathrm{f}_{\mathrm{H}_{2}}\right] /\left[\left[\mathrm{H}^{\mathrm{O}}\right]^{2}\right.$ :

$$
\dot{\mathrm{a}}=\frac{\mathrm{K}_{3} \cdot\left[\mathrm{H}^{+}\right]}{\mathrm{K}_{\mathrm{w}} \cdot\left[\mathrm{H}^{\circ}\right]}=\frac{\mathrm{K}_{5} \cdot\left[\mathrm{H}^{+}\right]}{\left[\mathrm{f}_{2}\right]^{1 / 2}} .
$$

where $\left[\mathrm{f}_{\mathrm{H}_{2}}\right.$ ] is the fugacity of hydrogen. Equation [14] indicates that the corrosion rate of iron under approximately constant pH will vary with

$\left[\mathrm{f}_{\mathrm{H}_{2}}\right]^{-1 / 2}$, where the partial pressure of hydrogen is related to the hydrogen fugacity by $f=\gamma \cdot p$, and $\gamma$ is 1.02 to 1.14 at $298 \mathrm{~K}$ and pressures between 21 and 210 atm (2.1 and $21 \mathrm{MPa}$ ) (33).

If the reduction of water indeed is the rate-controlling partial process. Eq. [14] suggests that the corrosion rate, under nominally constant $\mathrm{pH}$, would depend on the hydrogen partial pressure generated by the corrosion reaction as well as on a hydrogen overpressure applied to a solution in a capsule or static autoclave. Westerman (8) has performed corrosion experiments on Type A216 carbon steel in a PBB3 brine at $150^{\circ} \mathrm{C}$ in a static autoclave with initial hydrogen overpressures of 0,136 , and $204 \mathrm{~atm}(0,13.8$, and $20.7 \mathrm{MPa})$. Because additional hydrogen is generated during the corrosion process, the final hydrogen pressure at the conclusion of these tests is somewhat greater than the initial overpressure. The calculated incremental hydrogen pressures during the tests were $15.9,6.0$, and 1.6 atm $(1.61,0.61$, and $0.16 \mathrm{MPa}$ ), 
respectively, for the three nominal initial hydrogen overpressures (13). The corrosion rates obtained by Westerman are plotted in Fig. 4 as a function of total hydroger fugacity, including these incremental pressures. The best-fit line has a slope of -0.51 , consistent with the value of -0.5 predicted by Eq. [14]. For a slope of -0.5 , the equation for the line is given by

$$
P=5.40 \cdot f-0.5
$$

where $P$ is the corrosion rate in $\mathrm{mm} / \mathrm{yr}$ and $\mathrm{f}$ is the hydrogen fugacity in atmospheres at $423 \mathrm{~K}\left(150^{\circ} \mathrm{C}\right)$.

\section{Modeling of the Corrosion Process}

The dependences of corrosion rate on hydrogen overpressure (Fig. 4) and temperature (Fig. 2) can be combined to obtain an expression that describes the simultaneous effects of both variables. The simultaneous variation of $\ln P$ with $T$ and $f$ can be written in differential form:

$$
d \ln P=\left(\frac{\partial \ln P}{\partial T}\right)_{f} d T+\left(\frac{\partial \ln P}{\partial f}\right)_{T} d f .
$$

where the partial differential $\left(\frac{\partial \ln P}{\partial T}\right)_{f}$ is evaluated at constant fugacity (hydrogen overpressure) from Eq. [3], and $\left(\frac{\partial \ln P}{\partial \mathrm{f}}\right)_{T}$ is evaluated at constant temperature from Eq. [15]. Making these substitutions and integrating between the corrosion rate limits of $0.437 \mathrm{~mm} / \mathrm{yr}$ and $\mathrm{P}$, the 
temperature limits of $423 \mathrm{~K}$ and $T$, and the fugacity limits of 5 atm and $f$, finally gives

$$
P=8640 \cdot f^{-0.5} \cdot \exp (-3844 / T)
$$

The lower limits for Integration of Eq. [16] were selected to correspond to the mean corrosion rate at $423 \mathrm{~K}$. Thus, Eq. [3] yields a corrosion rate of $0.437 \mathrm{~mm} / \mathrm{yr}$ at $423 \mathrm{~K}$ where the hydrogen fugacity is assumed to be $\mathbf{5}$ atm for a flowing-autoclave test at this temperature. This hydrogen fugacity is equal to the total system pressure, which is slightly above the vapor pressure of water at $423 \mathrm{~K}$ (4.7 atr:). Significantly higher hydrogen overpressures and fagacities can build up in long-term, sealed-capsule tests at this temperature, and the increase in overpressure with time is consistent with the decrease in corrosion rate with test duration in such experiments.

Equation [17] can be used to analyze the corrosion of carbon steel in acid chloride solutions in isothermal sealed-capsule tests, where pressure of corrosion product hydrogen builds up with time and tends to suppress the corrosion process. The number of moles $\mathrm{n}_{\mathrm{Fe}}$ of Fe dissolved per unit time in the corrosion process is given by the expression

$$
\frac{\mathrm{dn}_{\mathrm{Fe}}}{\mathrm{dt}}=\frac{\mathrm{A \rho}}{\mathrm{M}} \cdot \mathbf{P}
$$

where $A$ is the specimen surface area in $\mathrm{mm}^{2}, \rho$ is the density of $\mathrm{Fe}$ in $\mathrm{g} / \mathrm{mm}^{3}$, and $\mathrm{M}$ is the molecular weight of $\mathrm{Fe}$. 
From the ideal gas law, the change in rydrogen partial pressure with time is

$$
\frac{d p}{d t}=\frac{R T}{V} \cdot \frac{d n_{H}}{d t} .
$$

where $\mathrm{V}$ is the volume of the gas space above the liquid in the capsule. Substituting Eq. [18] into Eq. [19] and assuming that one mole of $\mathrm{H}_{2}$ is generated for each mole of $\mathrm{Fe}$ dissolved, gives

$$
\frac{d p}{d t}=\frac{R T \rho}{M} \cdot \frac{A}{V} \cdot P
$$

With the approximation that the fugacity of hydrogen is equal to its partial pressure, Eq. [17] can be substituted into Eq. [20] to obtain

$$
\frac{\mathrm{dp}}{\mathrm{dt}}=8640 \cdot \frac{\mathrm{RT} \rho}{\mathrm{M}} \cdot \frac{\mathrm{A}}{\mathrm{V}} \cdot \mathrm{p}^{-0.5} \cdot \exp (-3844 / \mathrm{T})
$$

Solving for $p$ and integrating from $p=0$ to $p$ and $t=0$ to $t$ yields an expression for the hydrogen partial pressure in a sealed capsule test as a function of test temperature and time:

$$
p=551.7 \cdot\left(\frac{R T \rho}{M}\right)^{2 / 3} \cdot\left(\frac{A}{V}\right)^{2 / 3} \cdot t^{2 / 3} \cdot \exp (-2562.7 / T)
$$

In this expression, $R=82,050 \mathrm{~mm}^{3} \mathrm{~atm} / \mathrm{mole} \mathrm{K}, \rho=0.00787 \mathrm{~g} / \mathrm{mm}^{3}, \mathrm{M}$ $=55.85 \mathrm{~g} / \mathrm{mole}$, and the test time is expressed in years. Very substantial hydrogen pressures, of the order of $100 \mathrm{~atm}$, are predicted for a test 
time of one year at an $\mathrm{A} / \mathrm{V}$ ratio of $0.1 \mathrm{~mm}^{-1}$, 1.e., a small gas volume in the capsule.

An expression can be derived from Eq. [22] for expected corrosion penetration as a function of time in a sealed-capsule test. Again, with the approximation that the hydrogen pressure is equal to the hydrogen fugacity, one can substitute Eq. [22] into Eq. [17] to obtain

$P=\frac{d a}{d t}=\frac{8640}{(551.7)^{1 / 2}} \cdot\left(\frac{R T \rho}{M}\right)^{-1 / 3} \cdot\left(\frac{A}{V}\right)^{-1 / 3} \cdot \frac{\exp (-3844 / T)}{\exp (-1281.3 / T)} \cdot t^{-1 / 3}$

Rearranging Eq. [23] and integrating from $a=0$ to $a$ and $t=0$ to $t$ for the case where $\mathrm{p}=0$ at $\mathrm{t}=0$ gives the corrosion penetration, $\mathrm{a}$, as a function of time and the $A / V$ ratio:

$$
a=551.7 \cdot\left(\frac{R T p}{M}\right)^{-1 / 3} \cdot\left(\frac{A}{V}\right)^{-1 / 3} \cdot t^{2 / 3} \cdot \exp (-2562.7 / T)
$$

The corrosion penetration shows the same dependence on $t^{2 / 3}$ as the hydrogen partial pressure in a sealed-capsule test. Equation [24] is plotted in Fig. 5 for three values of A/V. Also plotted in Fig. 5 are data from sealed-capsule corrosion tests conducted by Westerman et al. (8) on A216 Grade WCA steel at $423 \mathrm{~K}$. The data generally conform to the predictions of Eq. [24] and suggest that A/V for Westerman's tests was typically of the order of $0.01 \mathrm{~mm}^{-1}$. 


\section{Application of Model to Waste Package Containers}

In order to calculate the corrosive penetration of an emplaced waste package as a function of time from Eq. [24], one must estimate the effective value of $\mathrm{A} / \mathrm{V}$ ior the container in the repository. As a simple approximation, one can assume that the hydrogen diffuses a limited distance into the host rock surrounding the container borehole and is effectively confined to this cylindrical region. Figure 6 shows the dependence of $A / V$ on salt porosity and "confinement radius," 1.e., the radius of the cylindrical region in the host rock within which the hydrogen is effectively contained. The waste package is assumed to consist of 12 spent fuel assemblies from a pressurized water reactor, i.e., the 12 PWR Consolidated Spent Fuel configuration (2). Figure 6 indicates, for example, that the $A / V$ ratio is $-10^{-4} \mathrm{~mm}^{-1}$ for an assumed host rock porosity of $10 \%$ and a confinement radius of $8 \mathrm{~m}$.

On the basis of $A / V$ ratios of $10^{-4}$ to $10^{-1} \mathrm{~mm}^{-1}$, best-estimate penetration curves for carbon steels have been calculated from Eq. [24] for three waste package temperature-time profiles for periods up to 1000 years. To wit: a defense high-level waste (DHLW) package with a maximum container/salt interface temperature of $\sim 334 \mathrm{~K}\left(61^{\circ} \mathrm{C}\right)$, a lightwater reactor intact spent fuel (ISF) package $\left(364 \mathrm{~K}\right.$ or $91{ }^{\circ} \mathrm{C}$ ), and a pressurized water reactor (PWR) consolidated spent fuel (12 PWR CSF) package $\left(407 \mathrm{~K}\right.$ or $\left.134^{\circ} \mathrm{C}\right)$. The temperature-time histories for these these packages were obtained from Reference 34, and the corrosive penetrations were calculated by using a simple numerical integration procedure in which the time after emplacement was divided into three 
intervals per logarithmic decade, beginning with 0.1 years after emplacement (13).

The results are summarized in Figs. 7-9. The DHLW package (Fig. 7), which has the lowest temperature profile, satisfies the suggested $25-\mathrm{mm}$ corrosion limit after 1000 years (35) for all of the A/V ratios considered. However, the lithostatic pressure in the repository is -148 atm at a depth of $600 \mathrm{~m}$ (4), and the hydrogen pressure exceeds this value after about 35 years for $\mathrm{A} / \mathrm{V}=10^{-1} \mathrm{~mm}^{-1}$. The total corrosion after the pressure of corrosion product hydrogen exceeds the lithostatic pressure (denoted by the dotted portions of the corrosion curves of Figs. 7-9) will be greater than that indicated in the figures, since the assumption that the hydrogen pressure will continue to build up and thereby suppress the corrosion process is not valid. It is unlikely that the hydrogen pressure will significantly exceed the lithostatic pressure because of creep and fracture of the host rock, resulting in hydrogen leakage.

The temperature profiles for the ISF package (Fig. 8) and the 12 PWR CSF package (Fig. 9) are higher than those for the DHLW Package, and the calculated penetrations after 1000 years are correspondingly higher. Both waste packages satisfy the suggested 25-mm corrosion limit for $A / V$ ratios of $\geq 10^{-3} \mathrm{~mm}^{-1}$. However, for the ISF package, the calculated hydrogen pressure exceeds the lithostatic pressure after -200 years for $A / V=10^{-2} \mathrm{~mm}^{-1}$ and after $\sim 15$ years for $A / V=10^{-1} \mathrm{~mm}^{-1}$. The corresponding times for the 12 PWR CSF package are 100 years and 4 years. The indicated penetrations for these curves at longer time periods are consequently too low, as was mentioned previously.

The corrosion curves of Figs. 7-9 are based upon the mean corrosion rate versus temperature behavior defined by Eq. [3] and the best fit curve 
of Fig. 2. If a safety factor is applied to these mean corrosion rates, the predicted penetrations after a given time period increase by the same factor. For example, if the factor-of-five "upper bound" rate curve of Fig. 2 is used in the analysis instead of the best-fit curve, the total corrosion penetrations plotted in Figs. 7-9 all increase by a factor of five. In that case, the corrosion penetration is greater than $25 \mathrm{~mm}$ under all conditions considered, except for the DHLW and ISF packages at an unrealisitically high $A / V$ value of $10^{-1} \mathrm{~mm}^{-1}$.

As discussed previously with respect to Eqs. [23] and [24], the corrosion rates observed in sealed-capsule tests decrease with time due to the build up of corrosion-product hydrogen. Because of this, the average corrosion rates obtained from such tests also decrease with increasing test duration. However, in the actual repository environment, a well-defined "confinement radius" within which the corrosion product hydrogen is contained probably does not exist. The host rock salt typically has a porosity of the order of $10 \%$, and higher porosities are typical of fractured or relithified rock salt (36). Consequently, significant diffusion of hydrogen into this porous medium is likely. The effective $\mathrm{A} / \mathrm{V}$ ratio for the environment is therefore expected to be very low $\left(<10^{-4}\right.$ $\mathrm{mm}^{-1}$ ), and the build up of hydrogen pressure is likely to be small. Thus, the use of experimental data from long-term sealed-capsule tests to estimate the corrosion life of emplaced canisters can lead to nonconservative results. This contrasts with the usual situation in which long-term experimental corrosion data are desirable in predicting extended service lives. 


\section{Effect of Brine Supply on Corrosion Rate}

The above calculations indicate that unacceptably high corrosion rates are expected for most waste package configurations and that these rates will not decrease to acceptable levels by the build up of corrosion product hydrogen or by the formation of protective corrosion product layers. However, sufficient brine must be supplied to the container/salt interface to support these corrosion rates. The question of adequate brine supply is examined for the case of two more recently proposed waste package configurations, namely the Consolidated High-level Waste (CHLW) package with a maximum interface temperature of $501 \mathrm{~K}\left(228^{\circ} \mathrm{C}\right)$ and the Spent Fuel PWR (SFPWR) package with a maximum interface temperature of $403 \mathrm{~K}\left(130^{\circ} \mathrm{C}\right)(37)$.

The additional complication of the effect of the $A / V$ ratio on corrosion rate was ignored in this analysis; 1.e., Eq. [3] rather than Eq. [23] was used to calculate corrosion rates as a function of temperature. The corrosion rates calculated from Eq. [3] correspond to a constant hydrogen fugacity of approximately $5 \mathrm{~atm}$, as noted above in the discussion of the integration limits used to obtain Eq. [17]. At $423 \mathrm{~K}$ $\left(150^{\circ} \mathrm{C}\right)$, the $\mathrm{A} / \mathrm{V}$ ratio implicit in Eq. [3] is of the order of $10^{-2} \mathrm{~mm}^{-1}$, since the sealed-capsule corrosion test data of Fig. 4 are included in the data base described by Eq. [3] (see Fig. 2).

By combining Eq. [3] with the calculated interface temperature versus time histories for these two waste packages with the assumption of unlimited brine, the corrosion rate versus time curves plotted against the right-hand vertical axes as the solid curves in Figs. 10 and 11 were obtained. On the basis of these corrosion rates, the calculated total 
penetrations after 1000 years were $133 \mathrm{~mm}$ for the CHLW package and $89 \mathrm{~mm}$.or the SFPWR package.

For the case of uniform corrosion over the surface of the container according to Eq. [4], one can directly convert the calculated corrosion rates for the two waste packages to brine consumption rates. Both packages have a surface area of $-13 \mathrm{~m}^{2}$, and a corrosion rate of $1 \mathrm{~mm} / \mathrm{yr}$ corresponds to a brine consumption rate of $0.0435 \mathrm{~m}^{3} /$ canister. $y r$. The left-hand vertical axes in Figs. 10 and 11 reflect this conversion, and the corrosion rate curves can be read against these axes to determine the amount of brine required to sustain the calculated corrosion rates.

This relationship between uniform corrosion rate and brine consumption rate can be used to assess the extent to which the corrosion process in a given repository is limited by the flow rate of brine to the container interface. Brine tends to flow up the thermal gradient to the container/salt interface, and McCauley and Raines (38) have calculated the rate of thermally induced brine flow for the CHLW and SFPWR packages in the Deaf Smith County site. Their results are plotted against the left-hand vertical axes as the dashed curves in Figs. 10 and 11 for two cases, namely a temperature gradient threshold and no threshold. In the first case, an assumption was made that thermally driven migration of brine ceases for a temperature gradient of less than $0.0125 \mathrm{~K} / \mathrm{mm}$, while in the second case no such threshold effect was postulated. Figures 10 and 11 indicate that, for both conditions, the supply of brine to both waste packages is less than that required to sustain the calculated corrosion rates after about one year. Thus, the results thus suggest that the corrosion process for an emplaced waste package would be limited by thermally driven brine migration over most of the emplacement period. 
Since the carbon steel container is capable of corroding at a higher rate than that established by thermally driven brine migration to the container, other modes of brine transport must be considered in an analysis of container performance, e.g., nonthermal brine migration due to concentration or stress gradients. Based upon 870-day brine migration experiments conducted at the Waste Isolation Pilot Plant (WIPP) Site near Carlsbad. NM, Nowak (39) has reported that the baseline nonthermally induced flow into a test borehole is approximately $10 \mathrm{~g} / \mathrm{m}^{2}$. day, or about $3650 \mathrm{~g} / \mathrm{m}^{2}$. yr. For a borehole containing a CHLW or a SFPWR container with a surface area of $13 \mathrm{~m}^{2}$, the nonthermal brine flow is about $0.047 \mathrm{~m}^{3} /$ canister. $\mathrm{yr}$. This flow rate is comparable to the maximum thermally induced flow calculated for the CHLW container during the first year after emplacement (Fig. 10), and it is substantially greater than the thermally induced flow thereafter. Furthermore, the flow is sufficient to support corrosion at the rate calculated by our analysis for essentially the entire 1000-year emplacement period. For the SFPWR container (Fig. 11), this nonthermal flow is greater by at least a factor of five than the maximum calculated thermal migration rate, and it is more than sufficient to support the maximum corrosion rate calculated by our analysis. In support of Nowak's results, Deal (40) has reported that nonthermal brine flow rates measured from 54 drilled holes on ceilings, floors, and walls at the WIPP Site ranged from about $10^{3}$ to $10^{4} \mathrm{~g} / \mathrm{m}^{2}$. yr, or about 0.013 to $0.13 \mathrm{~m}^{3} /$ canisterer $\mathrm{yr}$ for an assumed container surface area of $13 \mathrm{~m}^{2}$. 


\section{Brine Avallability}

The above discussion indicates that brine can migrate to the emplaced waste container by mechanisms other than thermally induced flow at a sufficient rate to suppart whe calculated reaction-rate-limited corrosicn rates. The question that remains is whether sufficient brine is available in the vicinity of an emplaced container to support either the calculated corrosion rates or the experimentally observed nonthermal brine migration rates over a 1000-year emplacement period.

A rough estimate of the available water can be made from geological stratigraphic data from the J. Friemal No. 1 core (Deaf Smith County, TX) (41). At the proposed emplacement depth of $820 \mathrm{~m}$ (bottom of container) in the LSA 4 emplacement horizon, a container 4.465-m high would intersect eight mudstone interbeds with a cumulative thickness of $-107 \mathrm{~mm}$. The remaining $4.358 \mathrm{~m}$ of container would intersect halite. Since the containers are to be positioned $22 \mathrm{~m}$ apart, a cylindrical volume $\sim 10 \mathrm{~m}$ in radius and 4.465- $\mathrm{m}$ high surrounds each container and could be considered to be a source of water to that container. This volume includes $\sim 33.6 \mathrm{~m}^{3}$ of mudistone and $1369 \mathrm{~m}^{3}$ of halite. If we assume a moisture level of $\mathbf{2 7 . 6}$ vol. percent in the mudstone interbeds and 1.06 vol. percent in the halite (42), the total amount of water contained in the cylindrical volume surrounding each container is about $23.8 \mathrm{~m}^{3}$ (9.3 $\mathrm{m}^{3}$ from the mudstone and $14.5 \mathrm{~m}^{3}$ from the halite). Over a 1000-year emplacement period, this volume of water is equivalent to a linear brine migration rate of $0.024 \mathrm{~m}^{3} /$ canister $\mathrm{yr}$, which is comparable to the nonthermal brine migration rates reported above. Additional brine 
is also available from the regions awove and below the container, which were not included in this calculation.

\section{Summary}

Carbon steel has been proposed as a container material for the isolation of high-level nuclear waste in a salt repository. Since brine entrapped in the bedded salt can migrate to the container by several transport processes, corrosion is an important consideration in the longterm performance of the waste package. The most aggressive brines naturally present in the salt repository are the high- $\mathrm{Mg}^{2+}$ inclusion brines, in which the hydrolysis of $\mathrm{Mg}^{2+}$ ions causes acidification above ambient temperature. Literature data relevant to the corrosion of carbon steels in anoxic high-Mg2+ repository brines and similar acid chloride solutions at temperatures between 298 and $673 \mathrm{~K}$ obey an Arrhenius dependence on temperature,in which the activation energy for the corrosion process is $32.0 \mathrm{~kJ} / \mathrm{mole}$. The rate-controlling step for the corrosion process is the cathodic reduction of solvent water to produce hydrogen on the basis of a comparison with electrochemical corrosion data for carbon steel in acid chloride solutions, and the dependence on hydrogen pressure, which is a direct consequence of this partial process. is $\left(\mathrm{p}_{\mathrm{H}_{2}}\right)^{-1 / 2}$.

An expression was derived for the simultaneous dependence of the corrosion rate for carbon steels on temperature and hydrogen overpressure in acid chloride solutions. For the situation in which the corrosion product hydrogen is contained within a sealed volume $\mathbf{V}$ surrounding the corroding material with a surface area $\mathrm{A}$, the corrosion 
rate varies as $(\mathrm{A} / \mathrm{V})^{-1 / 3}$, and the extent of corrnsion penetration increases with time as $t^{2 / 3}$. This derived expression is consistent with the results of sealed-capsule corrosion tests conducted in simulated high- $\mathrm{Mg}^{2+}$ salt repository brines.

By using this derived expression, the extent of corrosive penetration of a carbon steel container and the simultaneous build up of hydrogen pressure were calculated for three proposed waste package configurations for time periods of up to 1000 years. For an unlimited quantity of brine, the results indicated that only the package with the lowest temperature-time profile (maximum interface temperature $=$ $332 \mathrm{~K}$ ) satisfied a suggested corrosion limit of $\sim 25 \mathrm{~mm}$ after 1000 years. However, the calculated hydrogen pressure exceeded the lithostatic pressure of the repository within this time period. Relief of the excess hydrogen pressure would normally be expected in this situation, and the total corrosion of the waste package would be greater than that predicted by this analysis. In fact, because of the host rock salt porosity, the effective $A / V$ ratio for this medium would be expected to be very low, and relatively little hydrogen pressure would build up to impede the corrosion process. Thus, the use of experimental data from long-term sealed-capsule laboratory corrosion tests, where substantial buildup of corrosion-product hydrogen can occur, to predict the corrosion life of emplaced waste-package containers can lead to nonconservativt results.

Models for thermally induced brine migration to the container indicate that the relatively small amount of brine available through this process would limit the amount of corrosion penetration. However, if the experimentally observed rates of nonthermal brine migration into test boreholes persist over long time periods, they would be sufficient to 
support unacceptably high corrosion rates of carbon steels. A sufficient quantity of brine appears to be available in the region surrounding the emplaced containers to allow unacceptably high rates of corrosion over a 1000-year period. We concluded that the corrosion resistance of a carbon steel container is probably not sufficient to achieve the desired 1000-year life in a salt repository. The use of a corrosion-resistant cladding over the carbon steel or the development of methods to immobilize the brine in the vicinity of the container would probably be required to meet the performance objectives of the waste package. 


\section{REFERENCES}

1. Rule 10 CFR, Part 60, Disposal of High-Level Radioactive Wastes in Geologic Repositories, Federal Register 48, 120, p. 28217 (1983).

2. Westinghouse Electric Corporation. Waste Package Reference Conceptual Design for a Repository in Salt, BMI/ONWI-517, (February 1984).

3. R. E. Westerman and S. G. Pitman, in "Proceedings of the Symposium on the Scientific Basis for Nuclear Waste Management VII," Vol. 26, Materials Research Society Proceedings, p. 427, North-Holland, New York (1984).

4. D. E. Clark and D. J. Bradley, in "Proceedings of the 1983 Civilian Radioactive Waste Management Meeting," (CONF-831217), p. 285, U. S. Department of Energy, Washington, D. C. (February 1984).

5. R. E. Westerman, J. H. Haberman, S. G. Pitman, and J. S. Perrin, in "Proceedings of the 1986 ASME/ANS Nuclear Power Conference. Philadelphia (June 1986).

6. R. E. Westerman, J. H. Haberman, S. G. Pitman, B. A. Pulsipher, and L. A. Sigalla, Corrosion and Environmental-Mechanical Characterization of Iron-Base Nuclear Waste Package Structural Barrier Materials, Annual Report - FY 1984, PNL-5426, Pacific Northwest Laboratory (March 1986).

7. R. E. Westerman, in Waste Management Program Monthly Management Report, ONWI Nuclear Waste Management Program, compiled by M. R. Kreiter, Pacific Northwest Laboratory (July 1986).

8. R. E. Westerman, Waste Package Container Material Testing, handout at SRPO Review Meeting, Columbus, OH (September 25-26, 1986). 
9. R. E. Westerman. Investigation of Metallic, Ceramic, and Polymeric Materials for Engineered Barrier Applications in Nuclear-Waste Packages, PNL-3484, Pacific Northwest Laboratory (1980).

10. J. R. Park and D. D. Macdonald, Corrosion Science, 23, 295 (1983).

11. E. C. Potter and G. M. W. Mann, British Corrosion J., 1, 26 (1965).

12. J. W. Cobble, R. C. Murray, Jr., P. J. Turner, and K. Chen, HighTemperature Thermodynamic Data for Species in Aqueous Solution. EPRI NP-2400, Electric Power Research Institute (1982).

13. D. R. Diercks, A. B. Hull, W. K. Soppet, and T. F. Kassner, An Analysis of the Corrosion of Carbon Steels in Simulated Salt Repository Brines and Acid Chloride Solutions at High Temperatures, ANL/MCT....... Argonne National Laboratory (1988).

14. E. Smailos, W. Schwarzkopf, and R. Küster, Nuclear Science and Technology. Corrosion Behavior of Container Materic's for the Disposal of High-Level Wastes in Rock Salt Fori.zations, EUR-10400, Commission of the European Communities (1986).

15. J. W. Braithwaite and M. A. Molecke, Nucl and Chem. Waste Management, 1, 37 (1980).

16. V. Mirschinka and R. Odoj, in "Proceedings of the Symposium on the Scientific Basis for Nuclear Waste Management VII," Vol. 26. Materials Research Society Proceedings, p. 25, North-Holland, New York (1984).

17. S. D. Cramer and J. P. Carter, in "Geothermal Scaling and Corrosion," L. A. Casper and T. R. Pinchback, Eds., ASTM STP 717, American Society for Testing and Materials (1980).

18. R. D. MicCright, W. F. Frey, and G. E. Tardiff, Trans. Geothermal Resources Council, 4, 645 (1980). 
19. J. P. Carter and F. X. McCawley, J. Metals, 30 (3), 11 (1978).

20. R. D. McCright and R. E. Garrison, in "Geothermal Systems Materials: A Workshop/Symposium," COO-3904 (1978).

21. D. W. DeBerry, P. F. Ellis, and C. C. Thomas, "Materials Selection Guidelines for Geothermal Power Systems," ALO-3904-1 (1978).

22. R. D. McCright, Corrosion Behavior of Materials Exposed to Hypersaline Geothermal Brines, UCRL-85174, Lawrence Livermore Laboratory (1980).

23. F. X. McCawley, S. D. Cramer, W. D. Wiley, J. P. Carter, and P. B. Needham. Jr., Corrosion of Materials and Scaling in Low-Salinity East Mesa Geothermal Brines, USBMM RI-8504, U. S. Bureau of Mines (1981).

24. R. Quong and L. B. Owen, $L L L$ Industrial Support Program Test Results on Scale Control, Corrosion, $\mathrm{H}_{2} \mathrm{~S}$ Abatement, and Injection at the Salton Sea Geothermal Field in FY 79, UCID-18596, Lawrence Livermore Laboratory (1980).

25. C. S. Smith and P. F. Ellis III, Addendum to Materlals Selection Guidelines for Geothermal Energy-Utilization Systems, DOE/ET/27026-2, Radian Corporation (1983).

26. R. S. Pathania and E. G. McVey, "The Effect of Cooling Water Leakage on Corrosion os Steam Generator Materials," Paper 97, Corrosion '79 (1979).

27. A. R. Vaia, G. Economy, M. J. Wootten, and R. G. Aspden, "Corrosion Performance of $12 \%$ Chromium Stainless Steels in High Temperature Chloride Solutions," Paper 99, Corrosion '79 (1979).

28. M. J. Wootten, G. Economy, A. R. Pebler, and W. T. Lindsey. Jr., Materials Performance, 17(12), 30 (1978). 
29. G. Butler and G. Beynon. Corrosion Science, 7, 385 (1967).

30. D. W. Shannon. Corrosion of Iron-Base Alloys Versus Alternative Materials in Geothermal Brines, Interim Report - Period Ending October 1977, PNL-2456, Pacific Northwest Laboratory (1977).

31. E. N. Korzh, A. M. Sukhotin, and A. M. Borschevskil, Protection of Metals, 18, 75 (1982).

32. F. A. Posey, A. A. Palko, and A. L. Bacarella, Corrosivity of Geothermal Brines: Progress Report for Period Ending September 1977, Final Report, ORNL/TM-6308, Oak Ridge National Laboratory (1978).

33. G. J. VanWylen and R. E. Sonntag. Fundamentals of Chemical Thermodynamics, Second Edition, Revised Printing, John Wiley and Sons, New York (1976).

34. Conceptuai Design for Waste Packagees for Horizontal or Vertical Emplacement in a Repository in Salt, Office of Nuclear Waste Isolation, Battelle Memorial Institute, in press.

35. G. Jansen, Expected Waste Package Performance for Nuclear Waste Repositories in Three Salt Formations, BMI/ONWI-655, Office of Nuclear Waste Isolation, Battelle Memorial Institute (1987).

36. R. A. Freeze and J. A. Cherry, Groundwater, pp. 36-38, Prentice-Hall, Inc., Englewood Cliffs, NJ (1979).

37. E. G. McNulty, Expected Near-Field Thermal Performance for Nuclear Waste Repositories at Potential Salt Sites, BMI/ONWI-652, Office of Nuclear Waste Isolation, Battelle Memorial Institute (1987). 38. V. S. McCauley and G. E. Raines, Expected Brtne Movement at Potential Nuclear Waste Repository Sites, BMI/ONWI-654, Office of Nuclear Waste Isolation, Battelle Memorial Institute (1987). 
39. J. Nowak, Overview of the Near-Fleld Geochemistry of the U. S. Waste Isolation Pilot Plant, presented at the Joint USA/FRG Salt Near-Field Geochemistry Workshop. Albuquerque, NM (1987).

40. D. Deal, Moisture Content of the Salado Formation and Observed Brine Inflows in The WIPP Repository, presented at the Joint USA/FRG Salt Near-Field Geochemistry Workshop, Albuqureque, NM (1987).

41. S. Hovorka, B. Luneau, and S. Thomas, Stratigraphy of Bedded Halite in the Permian San Andres Formation Units 4 and 5, Palo Duro Basin, Texas, University of Texas at Austin, Bureau of Economic Geology (1985).

42. Environmental Assessment Overview, Deaf Smith County Site, TX. DOE/RW-0075, U. S. Department of Energy, OCRWM (1986). 
Table I. Representative Compositions (wppm) of Intrusion and Extrusion Brines, from Samples of Permian Basin Salt Horizon Cores (from Ref. (3)).

\begin{tabular}{lrc}
\hline Ion & $\begin{array}{c}\text { Intrusion } \\
\text { Brine } \\
\text { (PBB1) }\end{array}$ & $\begin{array}{c}\text { Inclusion } \\
\text { Brine } \\
\text { (PBB3) }\end{array}$ \\
\hline $\mathrm{Na}^{2+}$ & 123,000 & 23,200 \\
$\mathrm{Ca}^{2+}$ & 1,560 & 14,700 \\
$\mathrm{Mg}^{2+}$ & 134 & 53,200 \\
$\mathrm{~K}^{+}$ & 39 & 10,500 \\
$\mathrm{Sr}^{2+}$ & 35 & - \\
$\mathrm{Zn}^{2+}$ & 8 & 8 \\
$\mathrm{Cl}^{-}$ & & 210,000 \\
$\mathrm{SO}_{4}{ }^{2-}$ & 191,000 & 160 \\
$\mathrm{HCO}_{3-}^{-}$ & 3,200 & - \\
$\mathrm{Br}^{-}$ & 30 & 2,400 \\
$\mathrm{Fr}^{-}$ & 32 & - \\
\hline
\end{tabular}


Table II. Key to Data on General Corrosion of Plain-carbon Steels in Anoxdc Acid Chloride Solutions Plotted in Fig. 2

\begin{tabular}{|c|c|c|c|}
\hline \multicolumn{2}{|c|}{ Symbol/Solution } & \multirow[b]{2}{*}{ Westerman et al. } & \multirow{2}{*}{$\begin{array}{c}\text { Reference No. } \\
5, \mathbf{5 , 8}\end{array}$} \\
\hline $\mathbf{\square}$ & PBB3 Brine & & \\
\hline $\mathbf{\square}$ & PBB1/PBB3 & Westerman et al. & 6,7 \\
\hline $\mathbf{a}$ & Surrogate salt/PBB3 & Westerman et al. & 7,8 \\
\hline$x$ & $10 x$ or Acid Seawater & $\begin{array}{l}\text { Vala et al. } \\
\text { Wootten et al. }\end{array}$ & $\begin{array}{l}27 \\
28\end{array}$ \\
\hline$\Delta$ & $\mathrm{NiCl}_{2}, \mathrm{FeCl}_{2}$, or $\mathrm{HCl}$ & $\begin{array}{l}\text { Vala et al. } \\
\text { Potter and Mann }\end{array}$ & $\begin{array}{l}27 \\
11\end{array}$ \\
\hline $\mathbf{a}$ & $Q$ and $Z$ Brines & $\begin{array}{l}\text { Smailos et al. } \\
\text { Mirschinka and Odo] }\end{array}$ & $\begin{array}{l}14 \\
16\end{array}$ \\
\hline+ & $\begin{array}{l}\text { Salton Sea Geothermal } \\
\text { Brines }\end{array}$ & $\begin{array}{l}\text { Quong and Owen } \\
\text { McCright et al. } \\
\text { Carter and McCawley } \\
\text { DeBerry et al. }\end{array}$ & $\begin{array}{l}24 \\
18,20 \\
19 \\
21\end{array}$ \\
\hline - & $\begin{array}{l}\text { East Mesa and Krafla } \\
\text { Geothermal Brines }\end{array}$ & $\begin{array}{l}\text { Smith and Ellis } \\
\text { McCawley et al. } \\
\text { Shannon }\end{array}$ & $\begin{array}{l}25 \\
23 \\
30\end{array}$ \\
\hline $\mathbf{a}$ & Brine A & $\begin{array}{l}\text { Braithwaite and Molecke } \\
\text { Westerman }\end{array}$ & $\begin{array}{l}15 \\
9\end{array}$ \\
\hline$\bullet$ & $\mathrm{CaCl}_{2}$ Solution & Korzh et al. & 31 \\
\hline $\mathbf{0}$ & Acid $\mathrm{NaCl}$ Solution & Shannon & 30 \\
\hline 0 & $\begin{array}{l}\mathrm{MgCl}_{2} \text { or } \mathrm{NaCl} / \mathrm{MgCl}_{2} \\
\text { Solution }\end{array}$ & $\begin{array}{l}\text { Pathanla and McVey } \\
\text { Butler and Beynon }\end{array}$ & $\begin{array}{l}26 \\
29\end{array}$ \\
\hline
\end{tabular}


FIGURE CAPTIONS

Fig. 1. Calculated $\mathrm{pH}$ versus Temperature for Three Brines. These calculations ignore the effects of other constituents in these brines on $\mathrm{pH}$.

Fig. 2. Arrhenius Plot of General Corrosion Rate of Plain-Carbon Steels in Anoxdc Acid Chloride Solutions versus Temperature.

Fig. 3. Comparison of Electrochemical Corrosion Data of Posey et al. (Ref. 32) on A212B Carbon Steel $\left(\mathrm{pH}_{25}{ }^{\circ} \mathrm{C}=5-7\right)$ with Best-fit and Upper-bound Lines to Weight Loss Data of Fig. 2.

Fig. 4. Corrosion Rate of A216 Carbon Steel in PBB3 Brine at $423 \mathrm{~K}$ as a Function of Hydrogen Overpressure after Correcting for Hydrogen Generated During the Tests (data of Ref. (8).

Fig. 5. Plot of Calculated Penetration versus Time from Eq. [24] for Corrosion of Carbon Steel at $423 \mathrm{~K}\left(150^{\circ} \mathrm{C}\right)$ in a Sealed-Capsule Test for Three Values of A/V. Data obtained by Westerman et al. (8) from sealed capsule tests on A216 Grade WCA carbon steel are shown for comparison.

Fig. 6. Calculated A/V Ratio versus Radius of Hydrogen Confinement Region in Host Rock Surrounding the Borehole for the 12 PWR Consolidated Spent Fuel Package.

Fig. 7. Interface Temperature and Calculated Cumulative Corrosion of Carbon Steel Container for Defense High-Level Waste Package in Anoxic Acid Chloride Brine. Corrosion product hydrogen is assumed to be confined within a specified volume (fixed A/V ratio) surrounding the container. For the dotted portions of the 
penetration curves, the calculated hydrogen pressure exceeds the lithostatic pressure of 148 atm.

Fig. 8. Calculation of Fig. 7 for Intact Spent Fuel Waste Package.

Fig. 9. Calculation of Fig. 7 for 12 PWR Consolidated Spent Fuel Waste Package.

Fig. 10. Calculated Corrosion Rate and Corresponding Brine Consumption Rate for CHLW Waste Package. Also shown are the calculated thermally driven brine supply rates to the package and the corresponding corrosion rates that these supply rates can support.

Fig. 11. Calculated Corrosion Rate and Corresponding Brine Consumption Rate for SFPWR Waste Package. Also shown are the calculated thermally driven brine supply rates to the package and the corresponding corrosion rates that these supply rates can support. 


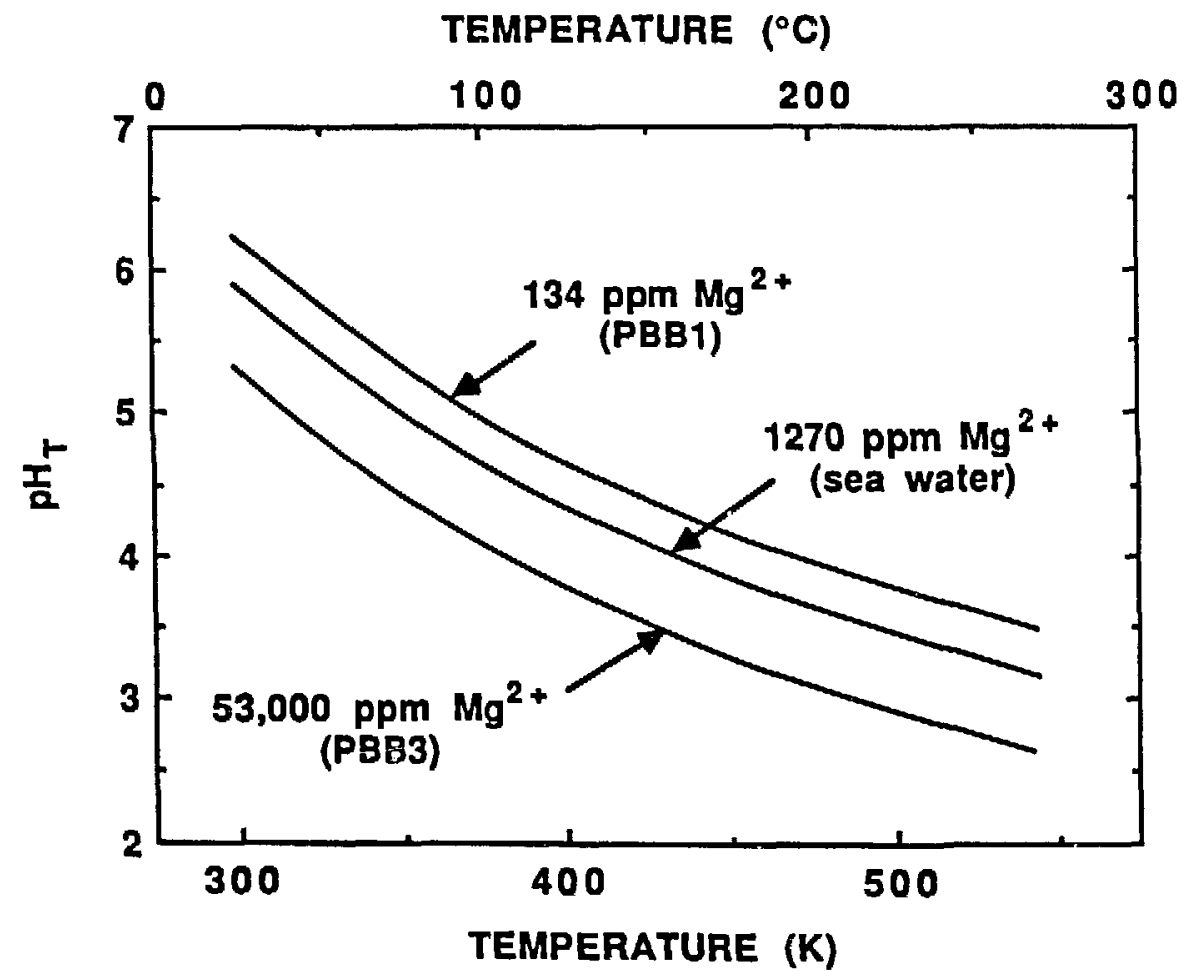

Fig. 1. Calculated $\mathrm{pH}$ versus Temperature for Three Brines. These calculations ignore the effects of other constituents in these brines on $\mathrm{pH}$. 


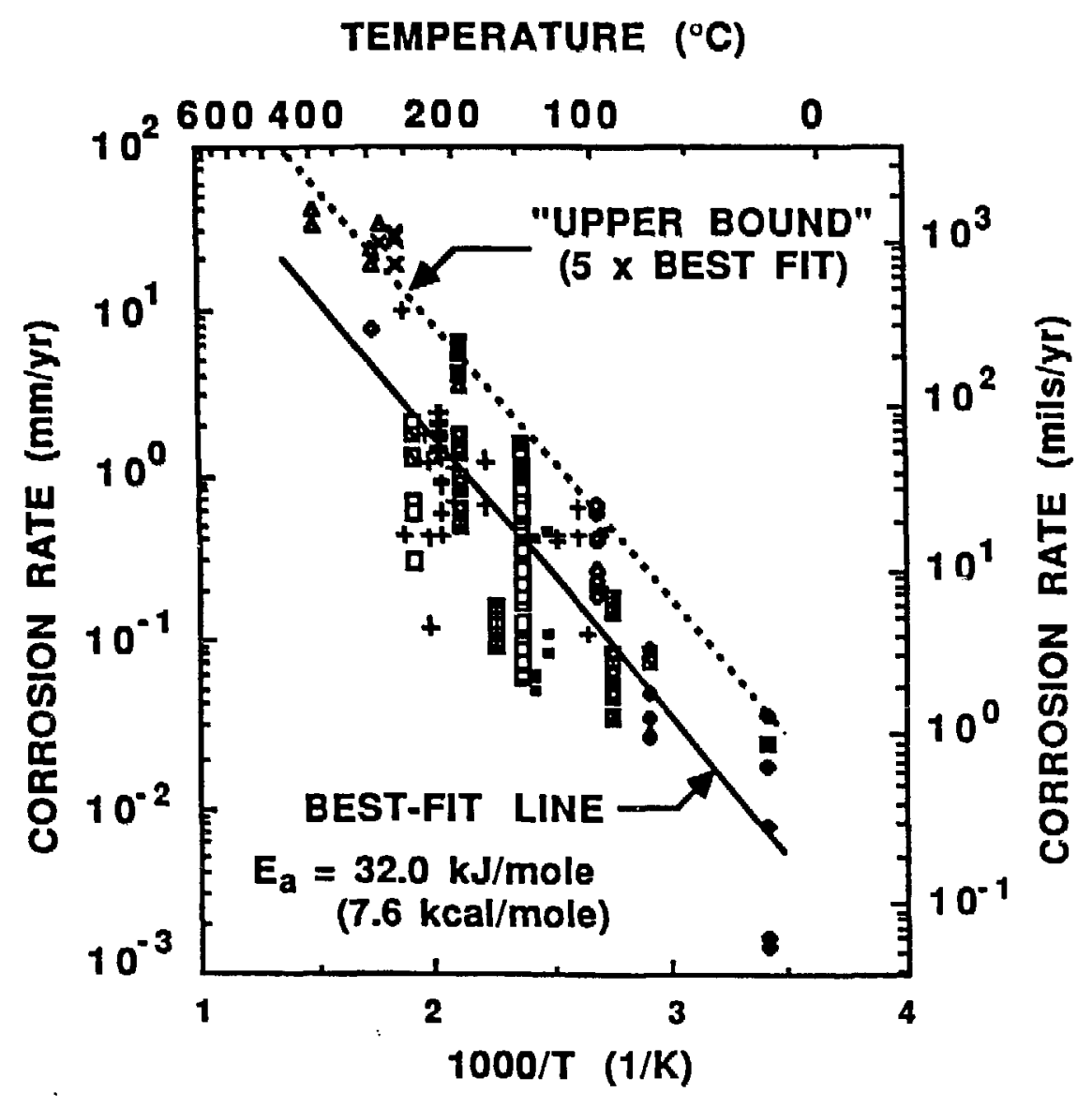

Fig. 2. Arrhenius Plot of General Corrosion Rate of Plain-Carbon Steels in Anoxic Acid Chloride Solutions versus Temperature. 


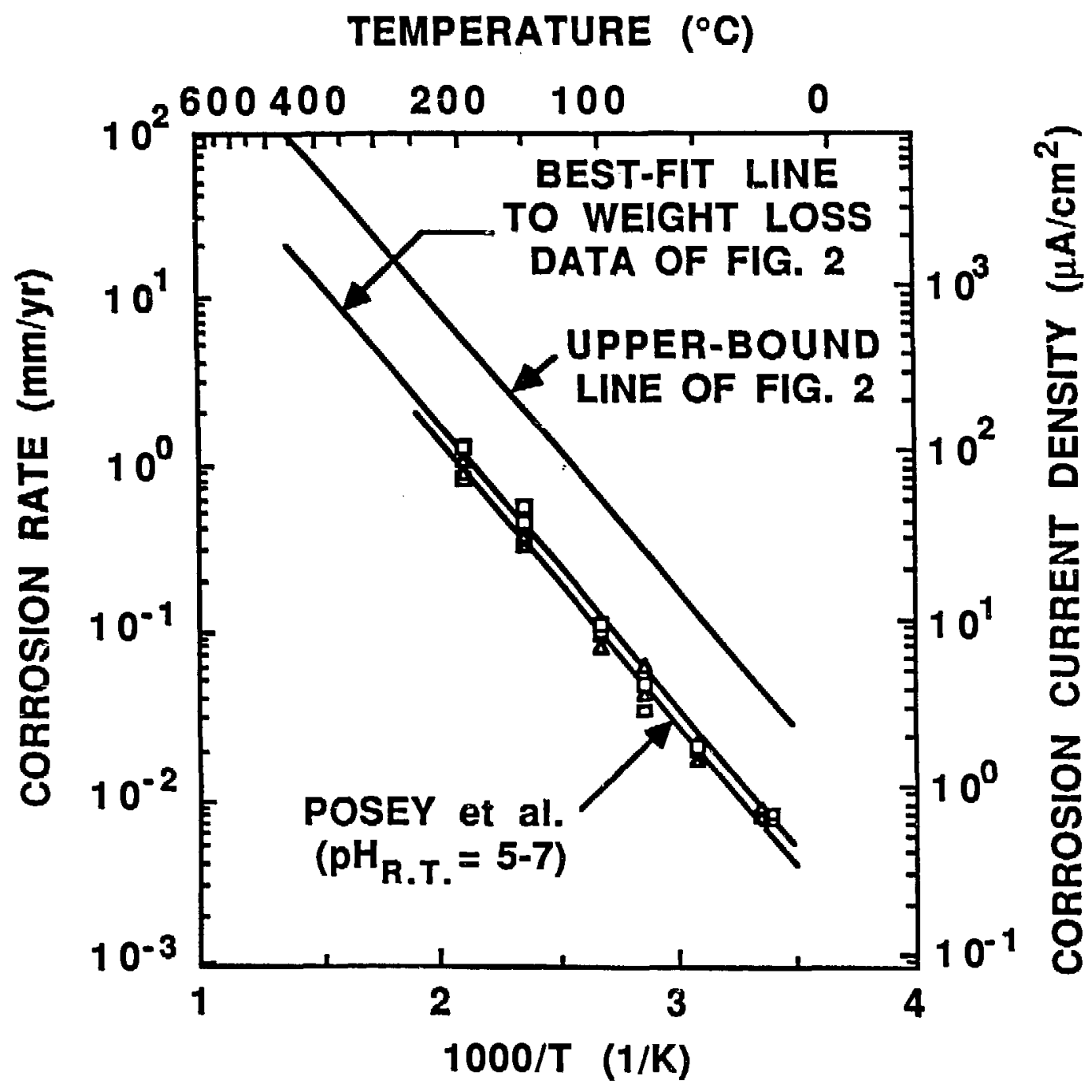

Fig. 3. Comparison of Electrochemical Corrosion Data of Posey et al. (Ref. 32) on A212B Carbon Steel $\left(\mathrm{pH}_{25^{\circ} \mathrm{C}}=5-7\right)$ with Best-fit and Upper-bound Lines to Weight Loss Data of Fig. 2. 


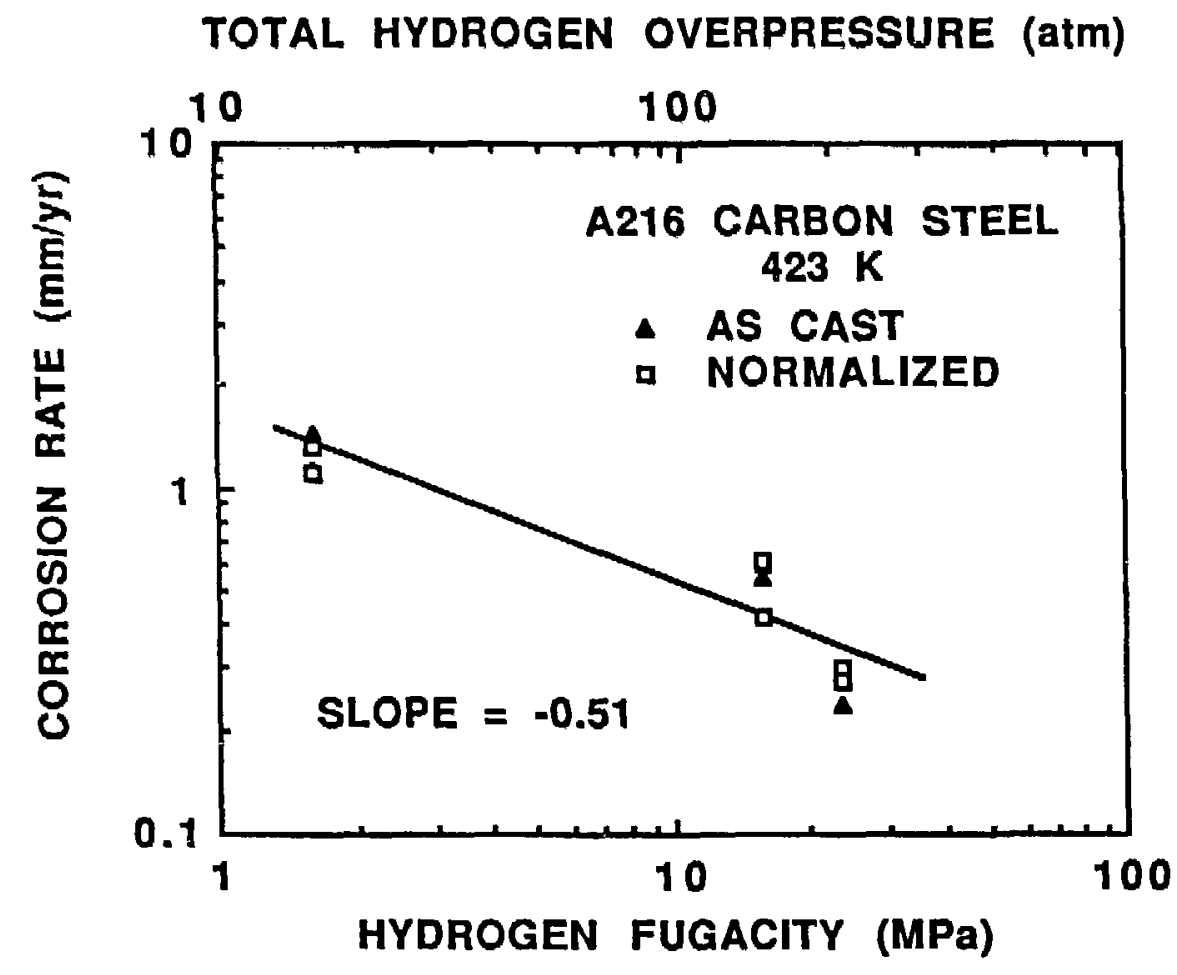

Fig. 4. Corrosion Rate of A216 Carbon Steel in PBB3 Brine at $423 \mathrm{~K}$ as a Function of Hydrogen Overpressure after Correcting for Hydrogen Generated During the Tests (data of Ref. (8). 


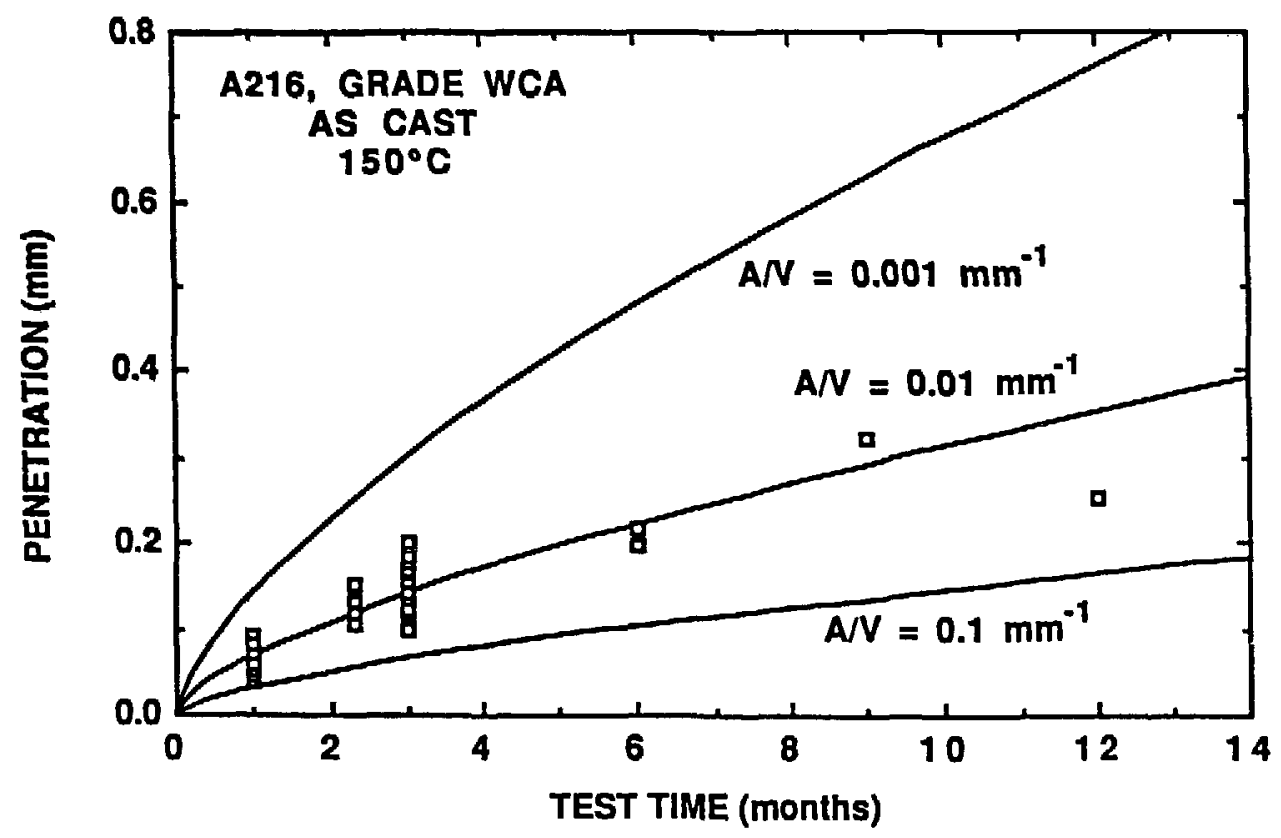

Fig. 5. Plot of Calculated Penetration versus Time from Eq. [24] for Corrosion of Carbon Steel at $423 \mathrm{~K}\left(150^{\circ} \mathrm{C}\right)$ in a Sealed-Capsule Test for Three Values of $A / V$. Data obtained by Westerman et al. (8) from sealed capsule tests on A216 Grade WCA carbon steel are shown for comparison. 


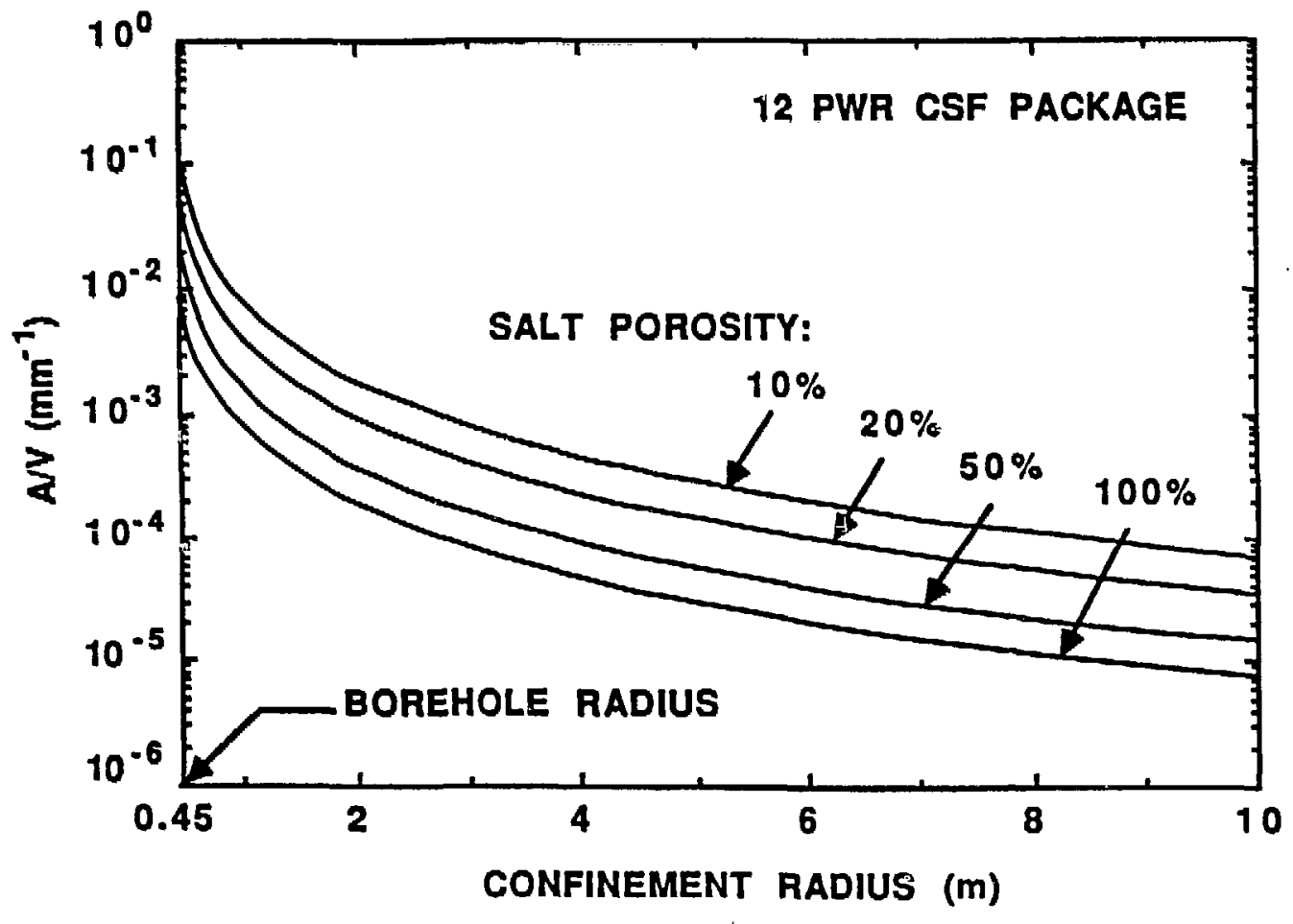

Fig. 6. Calculated A/V Ratio versus Radius of Hydrogen Confinement Region in Host Rock Surrounding the Borehole for the 12 PWR Consolidated Spent Fuel Package. 


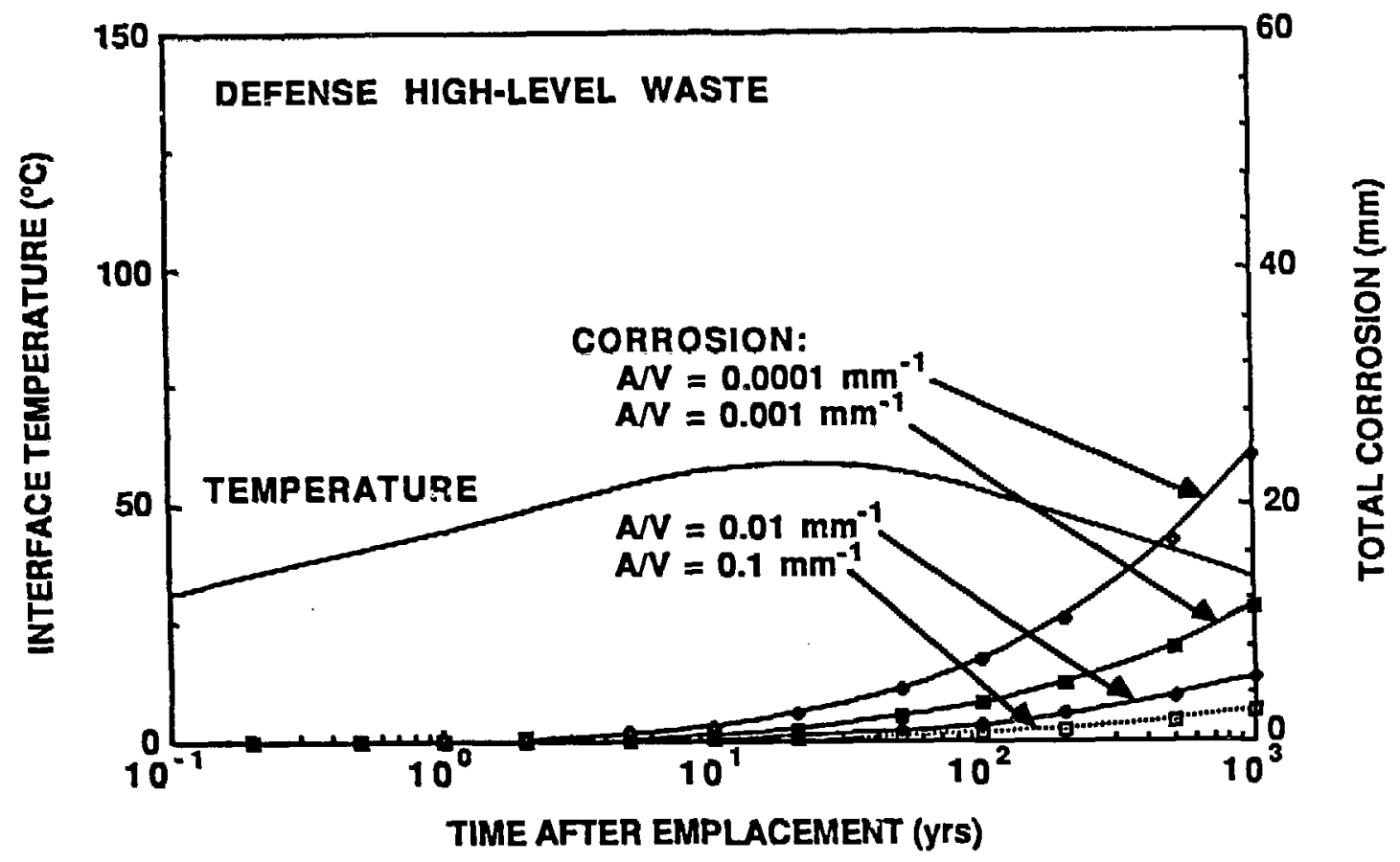

Fig. 7. Interface Temperature and Calculated Cumulative Corrosion of Carbon Steel Container for Defense High-Level Waste Package in Anoxic Acid Chloride Brine. Corrosion product hydrogen is assumed to be confined within a specified vclume (fixed $A / V$ ratio) surrounding the container. For the dotted portions of the penetration curves, the calculated hydrogen pressure exceeds the lithostatic pressure of 148 atm. 


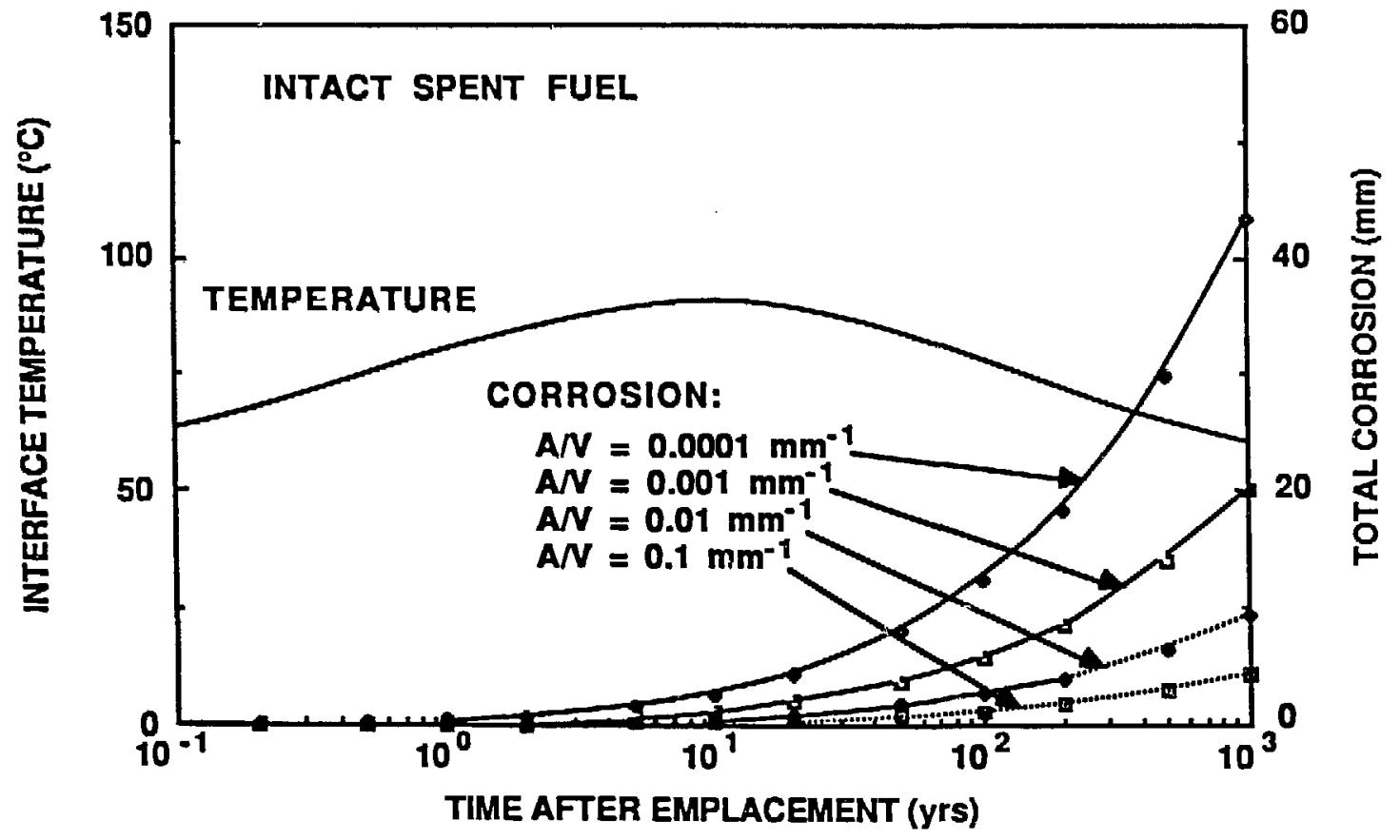

Fig. 8. Calculation of Fig. 7 for Intact Spent Fuel Waste Package. 


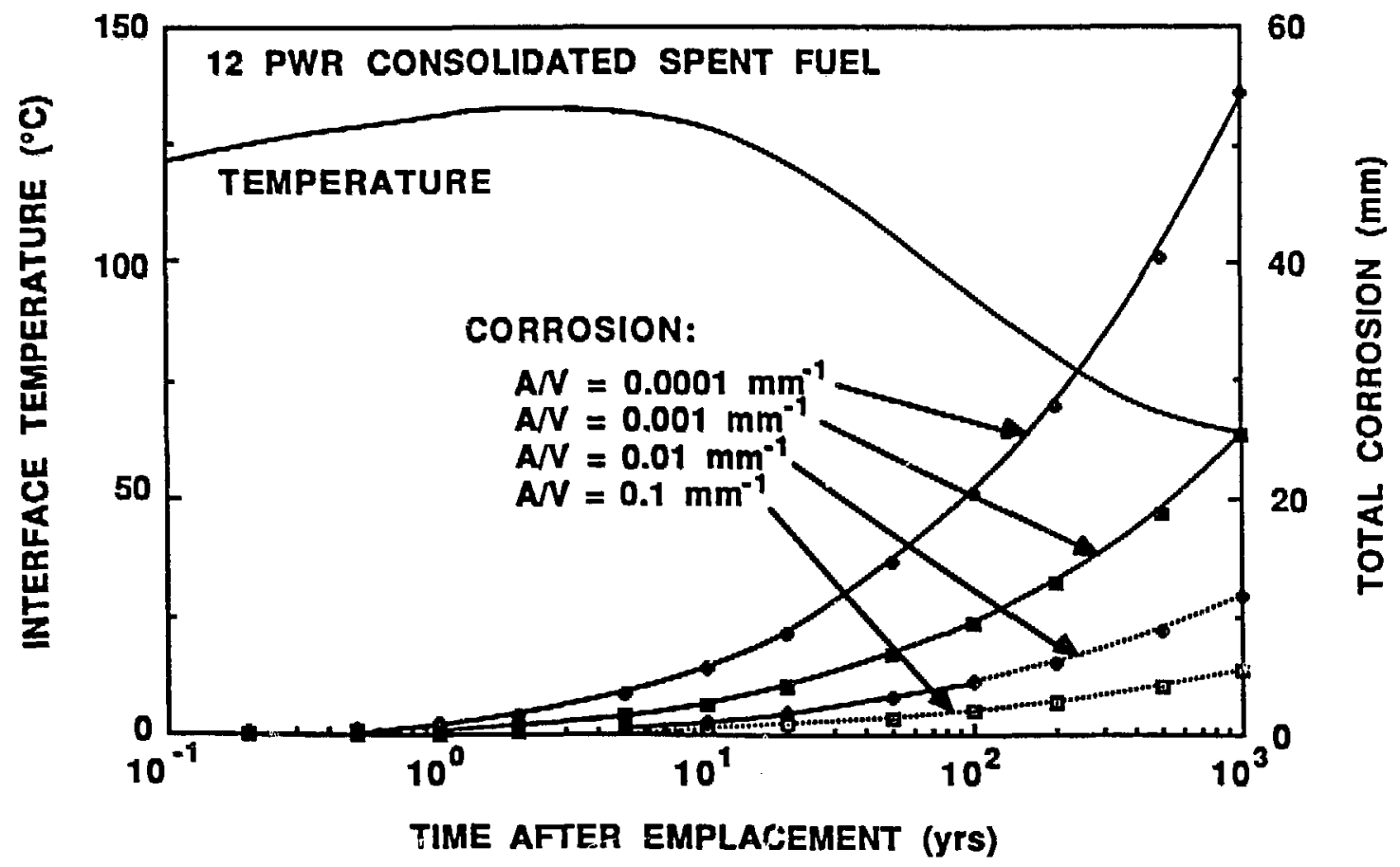

Fig. 9. Calculation of Fig. 7 for 12 PWR Consolidated Spent Fuel Waste Package. 


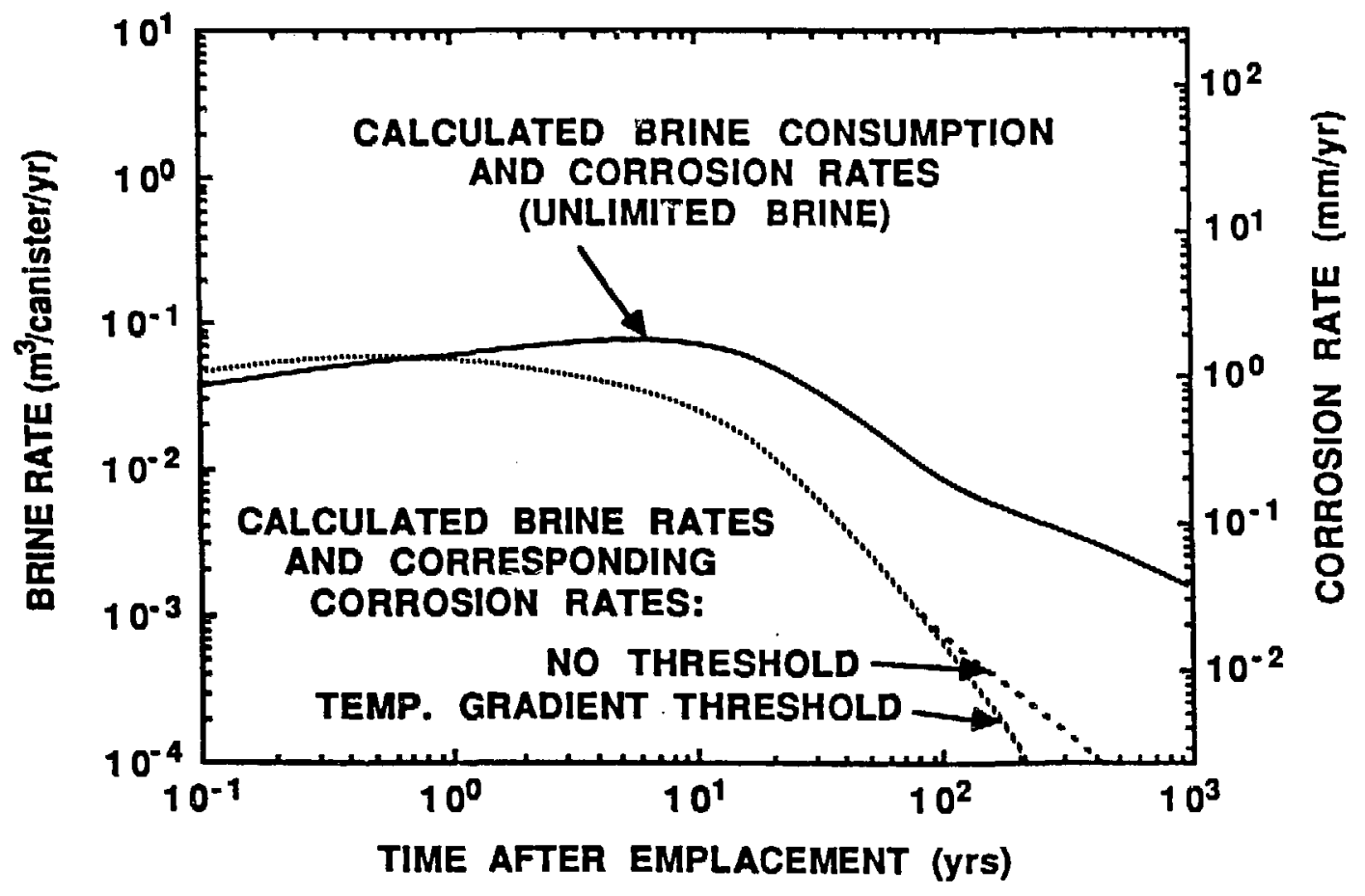

Fig. 10. Calculated Corrosion Rate and Corresponding Brine Consumption Rate for CHLW Waste Package. Also shown are the calculated thermally driven brine supply rates to the package and the corresponding corrosion rates that these supply rates can support. 


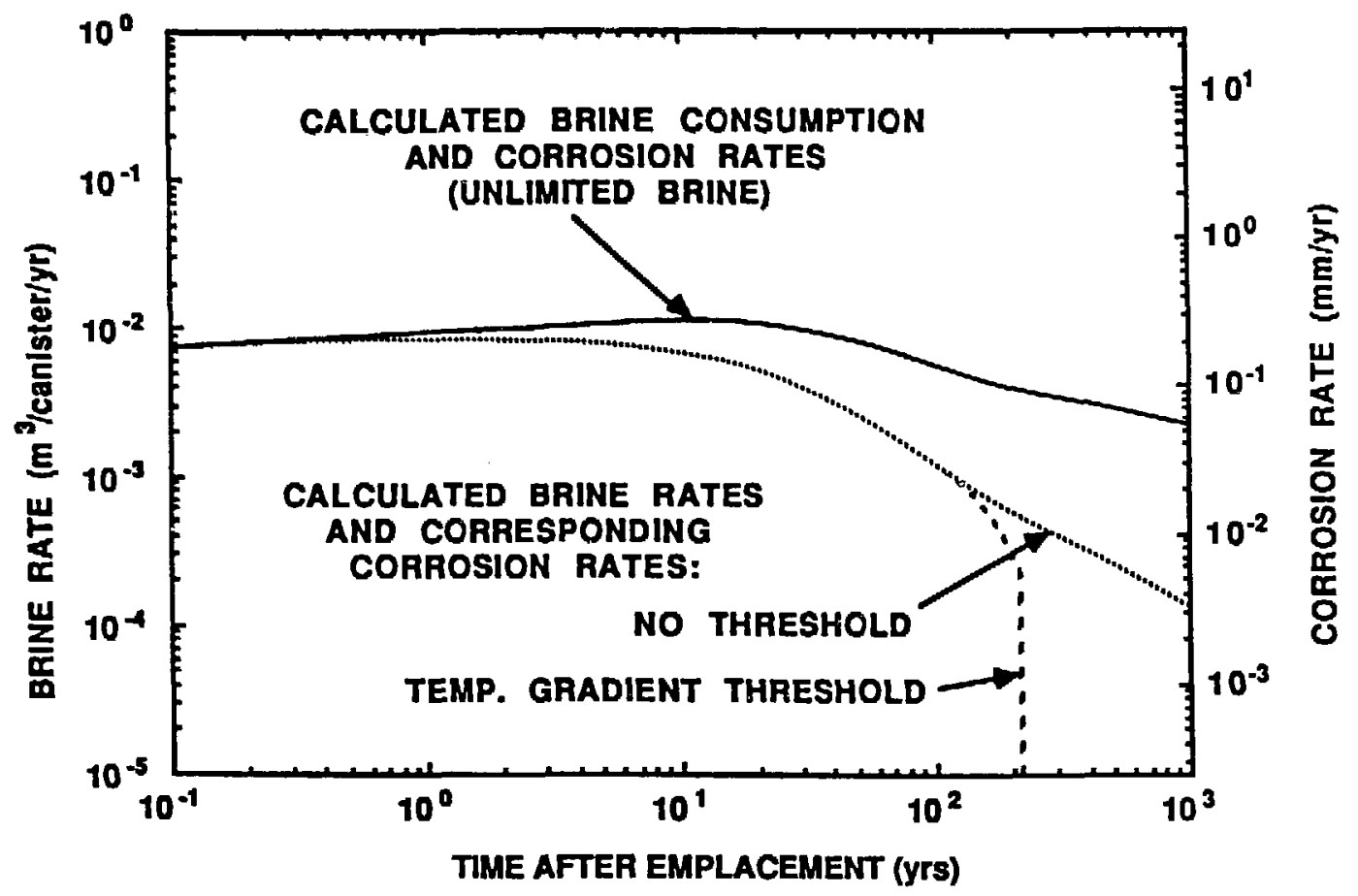

Fig. 11. Calculated Corrosion Rate and Corresponding Brine Consumption Rate for SFPWR Waste Package. Also shown are the calculated thermally driven brine supply rates to the package and the corresponding corrosion rates that these supply rates can support. 